\title{
Conservation and Application Scheme of Hominid and Other Vertebrate Footprints from Jeju Island, Korea
}

\author{
Chang Zin Lee ${ }^{1}$, Jeong Yul Kim ${ }^{2 * *}$, and Kyung Soo Kim ${ }^{3}$ \\ 'School of Science Education, Chungbuk National University, Chungbuk 361-763, Korea \\ ${ }^{2}$ Department of Earth Science Education, Korea National University of Education, Chungbuk 363-791, Korea \\ ${ }^{3}$ Department of Science Education, Chinju National University of Education, Gyeongnam 660-756, Korea
}

\begin{abstract}
This study intended to the optimal conservation method and to make an application scheme for the fossil locality of the Quaternary Hamori Formation at the northeastern coast of Mt. Songak. Many kinds of innumerable fossils are found from the Hamori Formation in the study area: Footprints of hominid, trace fossils of invertebrates, bird, artiodactyla, proboscidea, carnivores, unclassified footprints, and body fossils (arthropoda, gastropoda, mollusca, and plants). The formation has been outcropped and eroded out with innumerous fossils by the strong wave action of storm and typhoon. Korean government recognized the dangerous situation of the important fossils and decided to conserve the formation for the national heritage. Method D1 (conservation hall or museum on the fossil locality) may be the best way to protect the fossil locality from all the natural activities and to do the research, exhibition, education, and sightseeing together. The application of the geologic materials from the fossil locality should preferentially focus on the collection and research which should be accompanied by exhibition, education, and sightseeing. The application scheme may be stepped into three stages during 10 years: (1) systematic conservation and publicity during 2005-2007, (2) establishment of wellorganized museum during 2008-2010, and (3) international museum with the optimized roles 2011-2014.
\end{abstract}

Keywords: Hominid footprints, Hamori Formation, conservation, Jeju Island

\section{Introduction}

Many footprints of hominid and vertebrates and lots of animal and plant fossils are found from the Quaternary Hamori Formation at the Sangmori and Sagyeri beach of Daejeongeup, Jeju Island, Korea. Korean Cultural Heritage Administration recognized the acadenic value and nominated them as a natural heritage (Natural Monument No. 464) of Korea on the 5th of February 2004. The designation zone of Natural Monument No. 464 is $430 \mathrm{~m}$ in length and $300 \mathrm{~m}$ in width (Kim et al., 2004a-c). The natural heritage is increasingly threatened with destruction not only by the traditional causes of decay but also by natural formidable phenomena of damage or destruction: Typhoon, storm, heavy rain, currents, tides, and waves. Recentry Korean Cultural Heritage Administration is trying to conserve and preserve the natural heritage.

*Corresponding author: kimjy@knue.ac.kr

Tel: $82-43-230-3720$

Fax: 82-43-232-7176
The Korean government recognized the invaluable value of the fossils and geologic characteristics in the Hamori Formation and gave some financial support for some basic studies (Kim et al., 2004a; Kim et al., 2004b; Kim et al., 2004c; Kim et al., 2005; Namjejugun, 2005). Those studies were focused on the geologic information of the Hamori Formation, hominid footprints of the study area and Africa and Europe, construction project of conservation and exhibition facilities, and touring theme park around southwestern part of Jeju. After the studies, the Korean government believed that the study area should be carefully conserved as the national heritage. It also knew that there were no obstacles on the political and legal problems for the conservation including the construction works. Therefore, this study will address the conservation and application of the formation with the innumerable fossils and geologic contents.

The purpose of this study is to find the optimizing conservation method and to make the application scheme for the fossil locality of the Quaternary Hamori Formation at the northeastern coast of Mt. 


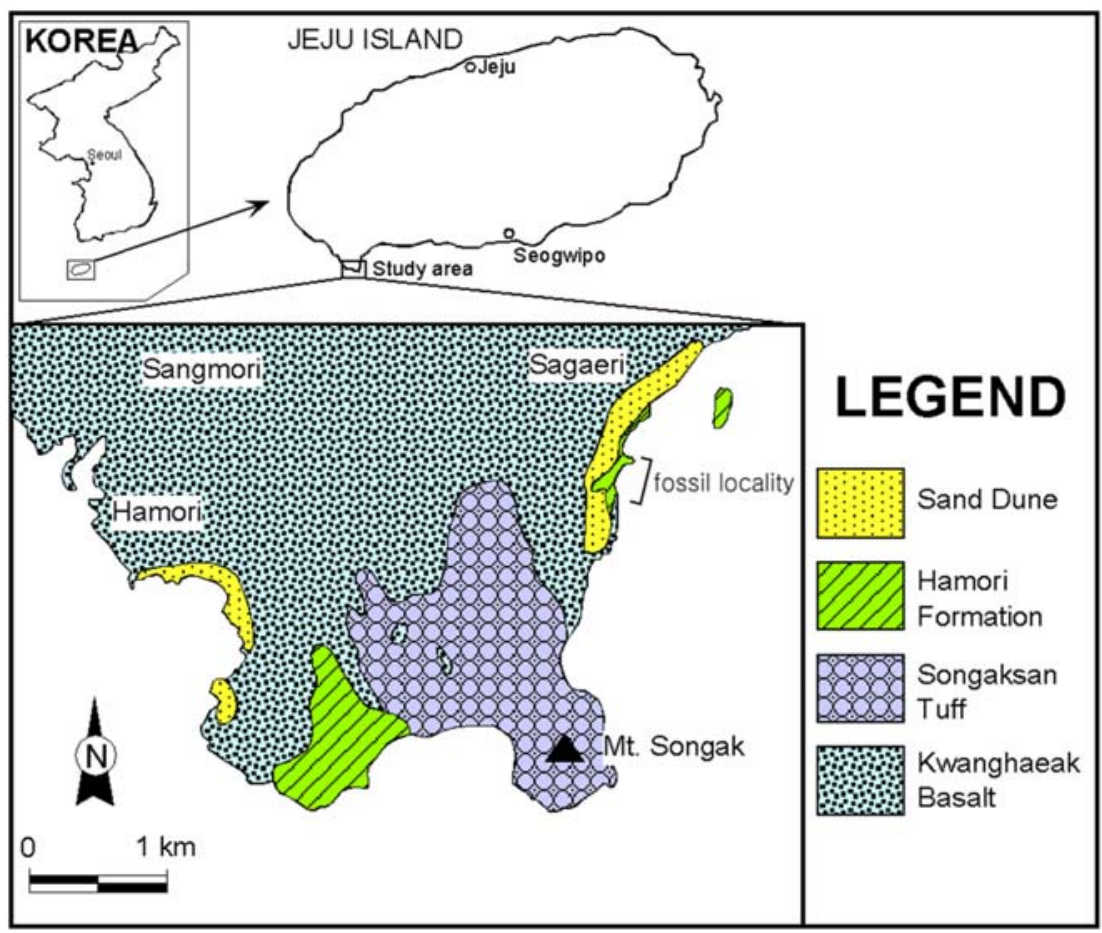

Fig. 1. Geologic map showing distribution of the Hamori Formation and fossil locality (Park et al., 2002; Kim et al., 2004). The geologic age of the Kwanghaeak Basalt, Songaksan Tuff, Hamori Formation, and Sand Dune: Quaternary Period.

Songak, Korea.

\section{Geologic Setting}

Jeju Island, $73 \mathrm{~km}$ long and $31 \mathrm{~km}$ wide, is mainly composed of plateau- and shield-forming lavas with numerous monogenetic volcanic cones. The study area is located at the southwestern margin of the Jeju Island. The geology in the vicinity of the study area is composed of the Kwanghaeak Basalt, Songaksan Tuff, Hamori Formation, and sand dune in ascending order (Fig. 1).

The Kwanghaeak Basalt is tholeiitic andesite with abundant olivine phenocryst and acicular feldspar laths in composition (Park et al., 2000). The geologic age of the Kwanghaeak Basalt is known as $0.6 \mathrm{Ma}$ (Lee et al., 1988). The Songaksan Tuff and Hamori Formation are the youngest units of all the rocks on Jeju Island. The Hamori Formation, which comprises volcaniclastic sediments or reworked tuff, is exposed along the northeast and east coasts of the Mt. Songhak (Park et al., 2000). The Hamori Formation seems to be gradually changed into the Songaksan Tuff distributed around Mt. Songak.

Numerous footprints attributable to hominids and vertebrates with many body fossils are found from the Hamori Formation exposed in the northeast coast of the Mt. Songak. The measured section of the formation shows the stratigraphic distribution of the lithology, sedimentary structures, footprints of the humans, mammals, and invertebrate fossils. The Hamori Formation, about $2.6 \mathrm{~m}$ in thickness is nearly horizontal and is unconformably covered on the Kwanghaeak Basalt (Kim, et al., 2004b, Kim and Kim, 2006, Kim et al., 2008).

The Hamori Formation of the northeast coast of Mt. Songak is mainly composed of basaltic granule conglomerate, basaltic pebbly sandstone, tuffaceous sandstone, and mudstone. Sedimentary structures including mud cracks and small wave ripple marks occurred on the bedding surface of laminated mudstone to shale and fine- to coarse- grained sandstone. 
Including many fossils of diverse vertebrate footprints and invertebrate traces may indicate shallow shoreline environment, especially semi-closed lagoonal or intertidal flat. Footprints were probably formed on this emerged or shallowly submerged muddy to sandy sediments which were partially dried or firm enough to walk upon the surface (Kim et al., 2004b).

Several years ago sand dune and beach were welldeveloped along the shoreline and covered on the fossil locality, now the beach and sand dune are disappeared or gradually decreased because of human activities of gathering sands and pebbles for construction materials. Sand dune, about $4 \mathrm{~m}$ in thickness, mainly comprises volcaniclastic sediments and reworked tuff with some molluscan fragments (Namjejugun, 2005).

\section{Climate and Typhoon}

Average temperature, average precipitation/year, greatest precipitation/day, and average wind speed of the study area are $17.4^{\circ} \mathrm{C}, 1,350.3 \mathrm{~mm}, 188.5 \mathrm{~mm}$, $7 \mathrm{~m} / \mathrm{sec}$ during 2006, which are affected by the warm marine air mass in summer time and the indirect and weak continental air mass in winter time. Generally two or three typhoons and 100 storms per year are passing through this study area. The big Typhoon Nari (average speed; $31 \mathrm{~km} / \mathrm{h}$ ) was passed through the study area on September 17, 2007 and affected seriously on the outcrops in the study area (http:// www.kma.go.kr/).

Average water temperature at the front sea of the study area is $20^{\circ} \mathrm{C}$, which is mainly influenced by the Tsushima current (a branch of Kuroshio current). Average tidal range is above $3 \mathrm{~m}$ (http://www.nori. go.kr/) and the fossil locality is located within tidal flat.

\section{Academic value of the Hamori Formation}

The measured columnar section of the Hamori Formation exposed in the northeast coast of Mt. Songak shows the stratigraphic distribution of the lithology, sedimentary structures, footprints of the hominid, mammals and apes, and invertebrate trace fossils (Kim et al., 2004).

Many kinds of innumerable fossils are found from the Hamori Formation in the study area as shown in Table 1. Footprints of hominid are found on the erosion surface of the bedding plane of the formation with many trace and body fossils; trace fossils of invertebrates, bird, artiodactyla, proboscidea, carnivores, and unclassified footprints, and body fossils of arthropoda, gastropoda, mollusca, and plants. The formation has been outcropped under the strong wave action by storm and typhoon, however fortunately small part of the formation is still remained. Although the formation is distributed within a small area, innumerable fossils are concentrated in the formation,

Table 1. Occurrence of fossils from the Hamori Formation in the study area (Modified from Kim et al., 2004a)

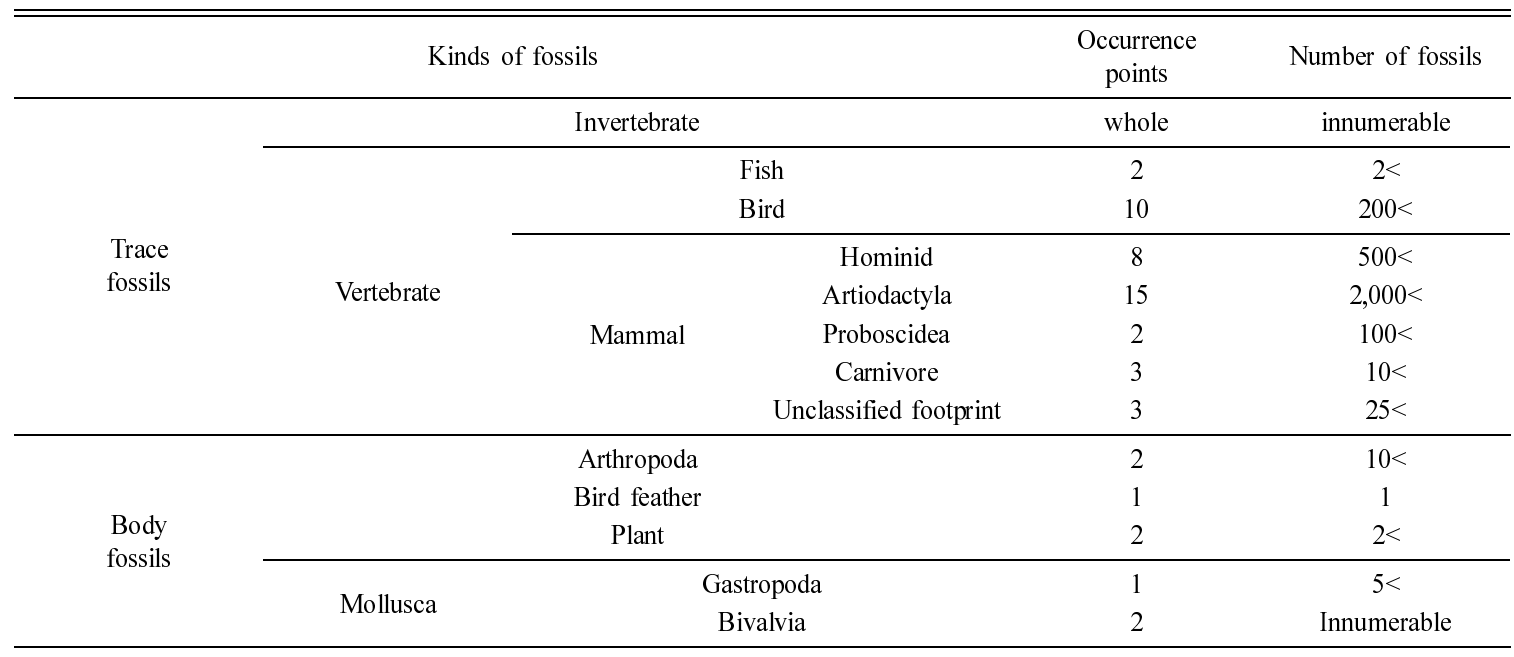


which may be used for the study and interpretation of the human life and natural environment.

\section{Conservation of the fossil locality}

The investigators of Namejugun (2005) suggested the necessity and methods of the conservation of the fossil locality on the premise of academic research and application; conservation activities on the bases of the detail investigation, main conserving method with supplementary methods, and systematic application of the fossil locality. They also analyzed the merits and demerits on five conservation methods for the fossil locality and proposed one optimal method of them (Table 2). In the present study, one more method and some supplementary explanation are added to the former methods (Table 2).

Method A is very simple and the fossils underground can be conserved by small expenses, however it is impossible to study on the fossils and geologic characteristics. Method B is also very good in conservation of those things in the museum, however, the Hamori Formation is too soft and breakable by weak shock to remove to another place.

Method E reclaimed land from all the foreshore area is very similar with method A in the point of burying the fossil locality. The natural scenery and fossil locality will be spoiled and deformed by the overburden deposits. If the formation is deformed or broken, it should be impossible to recover the lots of fossils and sedimentary structures in the formation. So the three methods above could be undesirable ideas for conservation.

The investigators of the former study proposed that method C (Construction of shore protection) would be the best idea as the first step of conservation. They thought that tides and waves should be very important erosive factors, so they decided that preferentially the breakwater construction should be necessary for the

Table 2. Merits and demerits of six conservation methods and the result (Modified from Namjejugun, 2005, Kim and Kim, 2006, and Kim et al., 2008)

\begin{tabular}{|c|c|c|c|}
\hline Method & Application example & Merits & Demerits \\
\hline $\begin{array}{l}\text { A: replica and burying under the } \\
\text { ground }\end{array}$ & Trackways of Laetoli in Tanzania & $\begin{array}{l}\text {-Permanent conservation available } \\
\text {-Small outlay }\end{array}$ & $\begin{array}{l}\text { Impossible for continuous } \\
\text { research and exhibition }\end{array}$ \\
\hline $\begin{array}{l}\text { B: Remove all the fossils and } \\
\text { strata to museum }\end{array}$ & $\begin{array}{l}\text { Hominid footprints at Nahoon } \\
\text { Point of South Africa }\end{array}$ & Permanent conservation available & $\begin{array}{l}\text {-Deformation and damage dur- } \\
\text { ing removal process }\end{array}$ \\
\hline $\begin{array}{l}\text { C: breakwater construction for } \\
\text { protection against the attack of } \\
\text { tides and waves }\end{array}$ & & $\begin{array}{l}\text { protection available for the dam- } \\
\text { ages from tides and waves }\end{array}$ & $\begin{array}{l}\text {-Spoilage of natural scenery } \\
\text {-Open state for typhoon and } \\
\text { storm }\end{array}$ \\
\hline $\begin{array}{l}\text { D1: Conservation hall or } \\
\text { museum on the fossil locality }\end{array}$ & $\begin{array}{l}\text { - Zigong dinosaur fossil site in } \\
\text { China; Exhibition hall } \\
\text { - Haenam Dinosaur fossil site in } \\
\text { Korea; conservation hall }\end{array}$ & $\begin{array}{l}\text {-Protection for all the natural and } \\
\text { human's activities } \\
\text {-Possible for Research, exhibition, } \\
\text { education, and sightseeing } \\
\text { together }\end{array}$ & $\begin{array}{l}\text {-Construction difficulties for the } \\
\text { conservation hall on the broad } \\
\text { fossil locality } \\
\text {-Spoilage of natural scenery } \\
\text {-Destructibility of the fossil local- } \\
\text { ity by building construction and } \\
\text { pressure } \\
\text {-Expensive and difficulties for the } \\
\text { government financial support }\end{array}$ \\
\hline $\begin{array}{l}\text { D2: Conservation covering on the } \\
\text { fossil locality }\end{array}$ & & $\begin{array}{l}\text {-Protection for all the natural and } \\
\text { human's activities } \\
\text {-Small outlay } \\
\text {-Possible for Research, }\end{array}$ & -Spoilage of natural scenery \\
\hline $\begin{array}{l}\text { E: Reclamation of the foreshore } \\
\text { land }\end{array}$ & & $\begin{array}{l}\text { protection available for the dam- } \\
\text { ages from tides and waves }\end{array}$ & $\begin{array}{l}\text {-Spoilage of natural scenery } \\
\text {-Damage from the overburden } \\
\text { deposits }\end{array}$ \\
\hline Result of South Jeju-gun, (2005) & \multicolumn{3}{|c|}{ C: Construction of shore-protection } \\
\hline Result of this study & \multicolumn{3}{|c|}{$\begin{array}{l}\text { D1: Museum on the fossil locality } \\
\text { If D1 will be impossible, D2 should be constructed preferentially }\end{array}$} \\
\hline
\end{tabular}




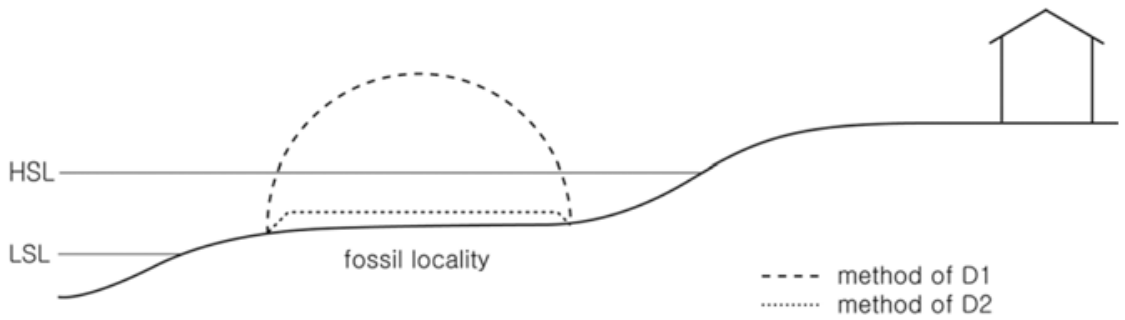

Fig. 3. Vertical section of the conservation hall or museum (D1) and covering (D2) on the fossil locality.

conservation of fossil locality. However they missed the big storm and typhoon with heavy rain passing several times in a year through the study area. Storm and typhoon should be more dangerous as the erosive factors than tides and waves.

The investigators of the former study pointed out that method D1 had two difficult and unsolved problems, which the fossil locality should be too broad (designation zone of Natural Monument 464: $430 \mathrm{~m}$ in length and $300 \mathrm{~m}$ in width) to construct a conservation building covered the locality and the pressure and construction of the building would destroyed the fossil locality.

However, we have different idea on the method D1 (Museum on the fossil locality). Fortunately we could be able to find out the concentrated area $(100 \mathrm{~m}$ in length, and $50 \mathrm{~m}$ in width in Fig. 4) of fossils and sedimentary structures and the Kwanghaeak Basalt under the Hamori Formation would be so strong and thick that there would be no possibility to be deformed or broken by the pressure of the museum building. However the study on the strength of the basalt will be necessary before the construction.

The method D1 should be able to protect from all the natural and human's activities and to do the research, exhibition, education, and sightseeing together (Figs. 3 and 4). Therefore the method D1 should be the best of all ideas in spite of expensive cost of museum construction and difficulties for the government financial support.

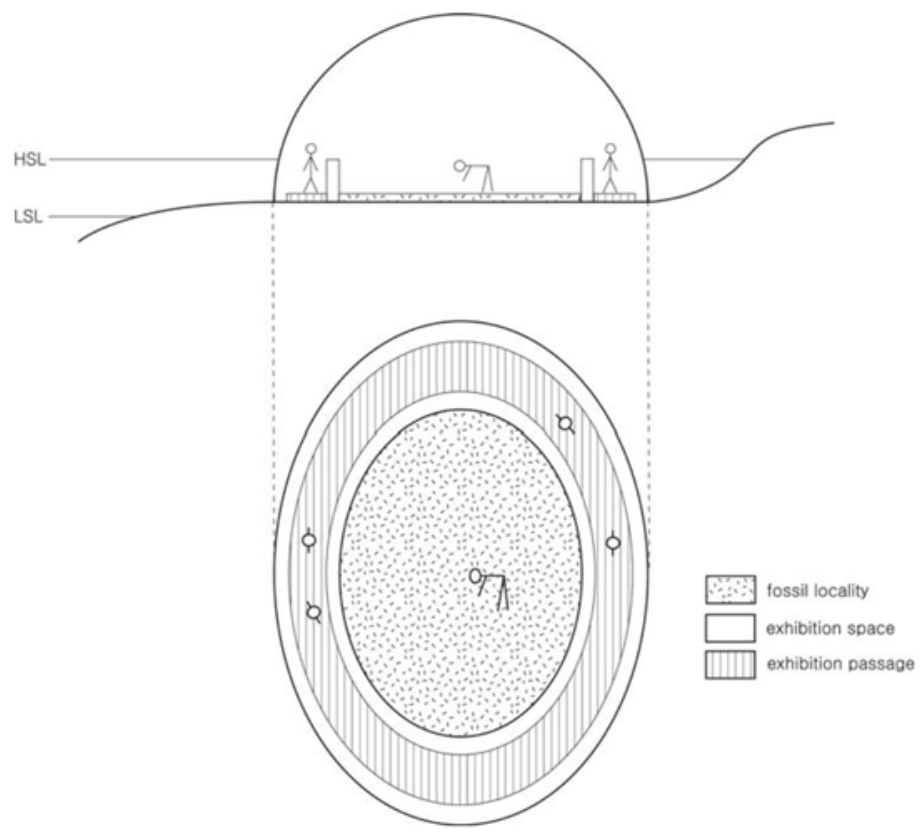

Fig. 4. Vertical and horizontal section of the conservation hall or museum (D1) on the fossil locality. 


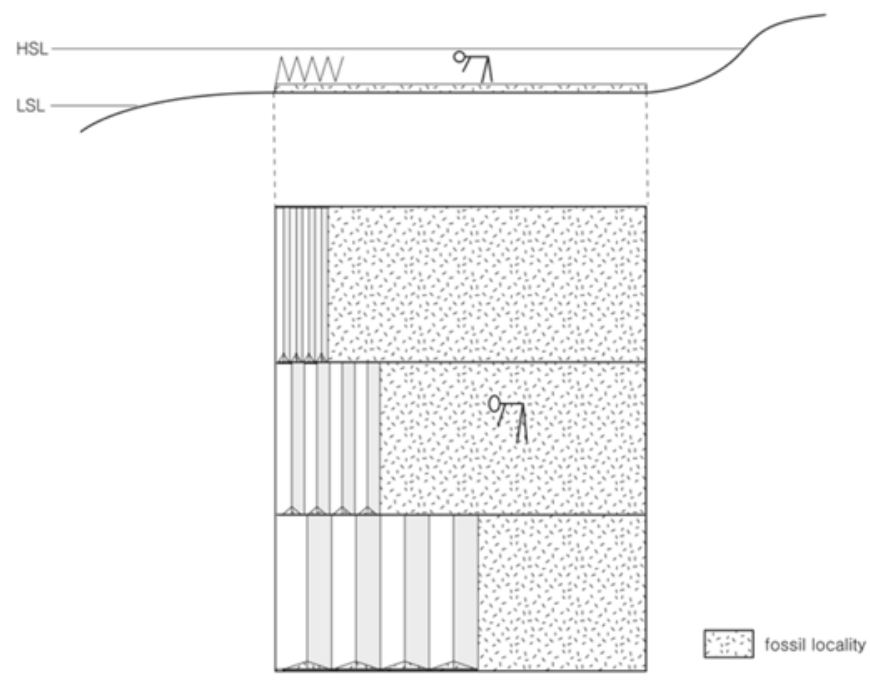

Fig. 5. Simplified vertical and horizontal section of covering (D2) on the fossil locality.

If the government budget would not be sufficient to build the museum (D1), method D2 should be done preferentially. The model and function of D2 are shown in Figs. 3 and 5. D2 can be constructed at a small outlay and D1 will be built on D2 construction after the sufficient financial support. D2 will conserve the fossil locality safely and also research is available by opening the cover (Fig. 5).

\section{Application scheme of the fossil locality}

The investigators of Namjejugun (2005) suggested 10 years project of the application of the geologic materials from the fossil locality. The project was focused on the research, exhibition, education, collection, and development of sightseeing contents and network with some touring resorts around the study area, However first of all, collection and research should be the most important functions and then exhibition, education, and tour would be the next.

They proposed three steps as the promoting strategy: Systematic conservation and publicity (the first step, 2005-2007), establishment of well-organized museum (the second step, 2008-2010), and international museum having the optimized roles (2011-2014). Now we will also accept the promoting strategy. The investigators (Namjejugun, 2005) suggested that gross working expenses in the investment plan would be needed around 50 million US\$ during 10 years. Therefore the establishment of the international museum having the optimized roles should be depending on the financial support from the government.

\section{Conclusion}

1. Many kinds of innumerable fossils are found from the Hamori Formation in the study area. They are footprints of hominids, trace fossils of invertebrates, birds, artiodactyla, proboscidea, carnivores, and unclassified footprints, and body fossils of arthropoda, gastropoda, mollusca, and plants.

2. The formation has been outcropped under the strong wave action by storm and typhoon and so should be eroded out with innumerous fossils. Korean government recognized the dangerous situation and decided that the formation should be carefully conserved for the national heritage.

3. The method D1 (the conservation hall or museum on the fossil locality) should be able to protect from all the natural and human's activities and to do the research, exhibition, education, and sightseeing together. Therefore the method D1 will be the best of all ideas in spite of expensive cost of museum construction and difficulties for the government financial support. 
4. The application of the geologic materials from the fossil locality should be preferentially focused on the collection and research and then exhibition, education, and sightseeing would be followed. The application scheme may be stepped into three stages during 10 years; systematic conservation and publicity during 2005-2007, establishment of well-organized museum during 2008-2010, and international museum having the optimized roles 2011-2014.

\section{Acknowledgment}

This work was supported by the research grant of the Chungbuk National University in 2008.

\section{References}

Kim, J.Y., Lee, C.Z., and Lim, J.D., 2004a, Basic research report on the footprint fossil locality in Namjeju coast, Korea. Korean Cultural Heritage Administration, 97 p. (Korean)

Kim, J.Y., Kim, K.S., Lee, C.Z., and Lim, J.D., 2004b, Occurrence of hominid and other vertebrate footprints of Jeju Island, Korea. In Kim, J.Y., Kim, K.S., Park, S.I., and Shin, M.K. (eds.), Proceedings of International Symposium on the Quaternary Footprints of Hominids and Other Vertebrates, Namjejugun, Korea, 1-
26.

Kim, J.Y., Kim, K.S., Park, S.I., and Shin, M.K. (eds.), 2004c, Proceedings of International Symposium on the Quaternary Footprints of Hominids and Other Vertebrates, Namjejugun, Korea, 175 p.

Kim, J.Y., Kim, K.S., Park, Locklery, M.G., and Matthews, N., 2008, Hominid ichnotaxonomy: An exploration of a neglectd discipline. Ichnos, 15, 126-139.

Kim, J.Y., Lee, C.Z., Lim, J.D., and Kim, K.S., 2005, Detail research report on the footprint fossil locality in Namjeju coast, Korea. Namjejugun, 384 p.

Kim, K.S. and Kim, J.Y., 2006, Review on the stratigraphy and geological age of the hominid footprints-bearing strata. Jeju Island, Korea. Journal of the Korean Earth Science Society, 27, 236-246.

Kim, K.S., Kim, J.Y., Kim, S.H., Lee, C.Z., and Lim, J.D., 2009, Preliminary report on hominid and other vertebrate footprints from the late Quaternary strata of Jeju Island, Korea. Ichnos, 16, 1-11.

Lee D.Y., Yun, S.K., Kim, J.Y., and Kim, Y.J., 1988, Quaternary geology of the Jeju Island. Korea Institute of Energy and Resources Report, KR-87-29, 45 p.

Namjejugun, 2005, Construction project of conservation and exhibition facilities on the footprint fossil locality in Namjeju coast, Korea. Namjejugun, 155 p.

Park, K.H., Cho, D.L., and Kim, J.C., 2000, Geological report of Moseulpo-Hanlim Sheet. Korea Institute of Geology, Mining and Materials, Daejeon, Korea, 18 p.

Korea meteorological Administration: http://www.kma.go.kr/ Korea Hydrographic and Oceangraphic Administration: http://www.nori.go.kr/

Manuscript received: February 17, 2009 Revised manuscript received: March 27, 2009

Manuscript accepted: April 6, 2009 